\title{
Evidence That Each S Cone in Macaque Fovea Drives One Narrow-Field and Several Wide-Field Blue-Yellow Ganglion Cells
}

\author{
Stan Schein, ${ }^{1,2}$ Peter Sterling, ${ }^{3}$ Ivy Tran Ngo, ${ }^{1}$ Teresa M. Huang, ${ }^{1}$ and Steve Herr ${ }^{1}$ \\ ${ }^{1}$ Department of Psychology, University of California, Los Angeles (UCLA), Los Angeles, California 90095-1563, ${ }^{2 B r a i n}$ Research Institute, UCLA, Los \\ Angeles, California 90095-1761, and ${ }^{3}$ Department of Neuroscience, University of Pennsylvania, Philadelphia, Pennsylvania 19104
}

A rule of retinal wiring is that many receptors converge onto fewer bipolar cells and still fewer ganglion cells. However, for each $\mathrm{S}$ cone in macaque fovea, there are two S-cone ON bipolar cells and two blue-yellow (BY) ganglion cells. To understand this apparent rule reversal, we reconstructed synaptic patterns of divergence and convergence and determined the basic three-tiered unit of connectivity that repeats across the retina. Each foveal S cone diverges to four S-cone $0 \mathrm{~N}$ bipolar cells but contacts them unequally, providing 1-16 ribbon synapses per cell. Next, each bipolar cell diverges to two BY ganglion cells and also contacts them unequally, providing $\sim 14$ and $\sim 28$ ribbon synapses per cell. Overall, each S cone diverges to approximately six BY ganglion cells, dominating one and contributing more modestly to the others. Conversely, of each pair of BY ganglion cells, one is dominated by a single $S$ cone and one is diffusely driven by several. This repeating circuit extracts blue/yellow information on two different spatiotemporal scales and thus parallels the circuits for achromatic, spatial vision, in which each cone dominates one narrow-field ganglion cell (midget) and contributes some input to several wider-field ganglion cells (parasol). Finally, because BY ganglion cells have coextensive $+S$ and $-(\mathrm{L}+\mathrm{M})$ receptive fields, and each $S$ cone contributes different weights to different BY ganglion cells, the coextensive receptive fields must be already present in the synaptic terminal of the $\mathrm{S}$ cone. The S-cone terminal thus constitutes the first critical locus for BY color vision.

Key words: retina; vision; cone; retinal ganglion cell; synapse; color vision; ribbon synapses; short-wavelength-sensitive cones

\section{Introduction}

Our understanding of the neural circuitry for color vision has progressed remarkably for the blue-yellow (BY) system, for several reasons. First, cones sensitive to short $(\mathrm{S})$ wavelengths are sparse and distributed regularly, with an action spectrum well separated from those of cones sensitive to middle (M) and long (L) wavelengths (de Monasterio et al., 1985; Shapiro et al., 1985; Szél et al., 1988; Wikler and Rakic, 1990; Curcio et al., 1991; Bumsted and Hendrickson, 1999). These properties allowed the S-cone mosaic to be plotted by a psychophysical method (Williams et al., 1981). Second, the synaptic terminals of $S$ cones are distinguishable ultrastructurally from the others (Klug et al., 2003), and an antibody recognizes S-cone opsin (Szél et al., 1988). Thus, the mosaic determined psychophysically has been

Received March 22, 2004; revised Aug. 11, 2004; accepted Aug. 11, 2004.

S.S., I.T.N., and T.M.H. were supported by National Institutes of Health (NIH) Grant EY11153 and by a grant from the University of California, Los Angeles Academic Senate; P.S. was supported by NIH Grant EY08124; and S.H. was supported by National Institute of Mental Health Training Grant MH15795-18 and NIH Grant EY11153. We thank Jim Gayed and Jack Ribble for helping to develop the hybrid synaptic surface for the cone terminal (Fig. 1); Vanessa Preciado for completion of Figure 1; Dr. Yoshihiko Tsukamoto, Patricia Masarachia, and Sally Shrom for preparing the electron microscopic material; and Kazuki Uema and Lisa Travis for printing. We also thank Hannah Smithson (University of Cambridge, Cambridge, UK), who kindly reviewed this manuscript and suggested we perform the investigation that we report in Results (Random numbers of central elements give almost the standard pattern).

Correspondence should be addressed to Dr. Stan Schein, Department of Psychology, Franz Hall, Mailcode 951563, University of California, Los Angeles, Los Angeles, CA 90095-1563. E-mail: schein@ucla.edu.

DOI:10.1523/JNEUROSCI.1063-04.2004

Copyright $\odot 2004$ Society for Neuroscience $\quad$ 0270-6474/04/248366-13\$15.00/0 confirmed by dye staining, electron microscopy, and immunostaining (de Monasterio et al., 1981; McCrane et al., 1983; Ahnelt et al., 1994b; Kolb et al., 1997).

Third, the wide spacing between $S$ cones allowed bipolar cells that skip nearby cones in favor of distant ones to be recognized as S-cone specific (Mariani, 1984). Tracing the connections of this bipolar cell was further assisted by its affinity for an antibody against cholecystokinin (Kouyama and Marshak, 1992, 1997; Wässle et al., 1994), showing that the dendritic tips of this bipolar cell are central elements that invaginate $S$ cones; indeed, this type of bipolar cell provides all the central elements of the $S$ cone (Herr et al., 2003). Invaginating central elements express the mGluR6 receptor that depolarizes bipolar cells at light onset (Vardi et al., 2000). Thus, this cell is an ON bipolar cell; in agreement, its axon descends to the ON half of the inner synaptic layer (Mariani, 1984; Kouyama and Marshak, 1992, 1997; Dacey, 1993).

Fourth, based on the accumulation of functional (Wiesel and Hubel, 1966; de Monasterio and Gouras, 1975) and anatomical knowledge, Rodieck (1991) predicted that BY ganglion cells should be bistratified, with one tier of dendrites excited by S-cone ON bipolar cells and the other tier excited by M/L-cone OFF bipolar cells. This prediction was confirmed by combined electrophysiology and intracellular staining in peripheral monkey retina (Dacey and Lee, 1994; Ghosh et al., 1997) and by reconstructing circuits in the fovea (Calkins et al., 1998). Fifth, ultrastructure allowed identification of an S-cone OFF pathway: S 
A

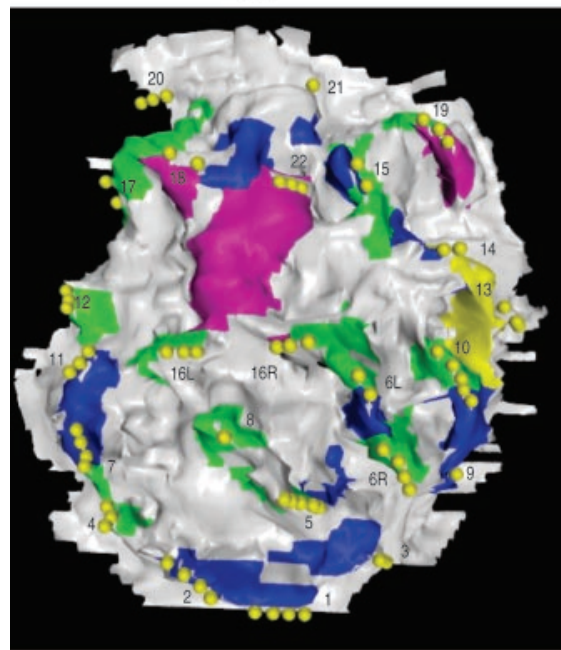

B

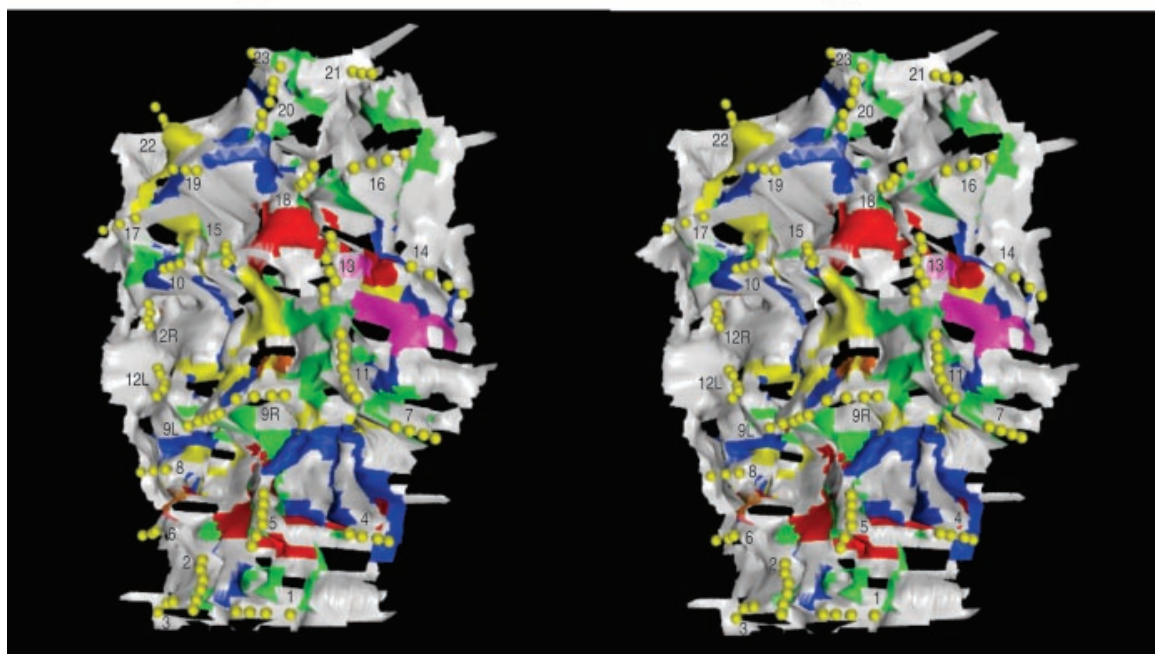

Figure 1. Foveal S-cone terminals express more than 20 active zones and contact more than 305 -cone $0 \mathrm{~N}$ bipolar cell dendrites provided by four or five bipolar cells. In these stereo reconstructions of the synaptic surfaces of two foveal $S$ cones, each cluster of yellow spheres indicate the site where a synaptic ribbon anchored to the presynaptic membrane. Thus, each cluster marks an active zone (numbered) where synaptic vesicles were released. Each active zone was presynaptic to a triad of postsynaptic processes, but the regions occupied by horizontal cell spines were excised (see Materials and Methods). Here, we show only the central processes (i.e., the $0 \mathrm{~N}$ bipolar cell dendrites) as colored patches. $A$, Terminal 35 contained 24 active zones that were presynaptic to 31 central elements from four different $\mathrm{S}$-cone $0 \mathrm{~N}$ bipolar cells. Each color codes for a different bipolar cell, with each bipolar cell providing the number of central elements indicated in Figure 2 (see also Herr et al., 2003, their Table 2A). B, Terminal 52 (modified from Herr et al., 2003, their Fig. 9B) contained 25 active zones that were presynaptic to 43 central elements from five different $S$-cone $0 \mathrm{~N}$ bipolar cells, with numbers provided in Figure 2. Of five (orange) triad-associated contacts, 1, 2, 1, and 1 are provided by the bipolar cells colored green, blue, yellow, and cyan, respectively; two of these contacts are visible in this view.

The pattern of synaptic weights reveals two kinds of BY ganglion cell, one dominated by a single $S$ cone and one diffusely driven by several. Thus, chromatic and achromatic systems are similar in using both narrow-field and wide-field cells to cover the same territory.

\section{Materials and Methods}

The detailed methods of this experiment were reported by Tsukamoto et al. (1992) and Herr et al. (2003). In brief, after perfusion with a fixative containing glutaraldehyde and paraformaldehyde, a retina was removed from an adult (6 $\mathrm{kg}$ ) male (Macaca fascicularis) monkey that had been anesthetized $(10 \mathrm{mg} / \mathrm{kg}$ ketamine, followed by $40 \mathrm{mg} / \mathrm{kg}$ pentobarbital) and prepared for electron microscopy. A series of 319 ultrathin $(90 \mathrm{~nm})$, serial vertical sections was cut parallel to the horizontal meridian, through the foveal center, and the region from 460 to 640 $\mu \mathrm{m}$ nasal to the foveal center was photographed en montage. Because of lateral displacement of photoreceptor terminals from inner and outer segments (Schein, 1988), this region is centered at an eccentricity of $\sim 1^{\circ}$, well within the fovea, which extends to $2.5^{\circ}$ in the macaque monkey (Polyak, 1941). Within this region of retina, we identified all of the $\mathrm{S}$ cones $(n=6)$ and S-cone ON bipolar cells $(n=12)$ (Mariani, 1984; Kouyama and Marshak, 1992), along with all of their synaptic contacts (Herr et al., 2003; Klug et al., 2003). We also incorporated in our analysis data from Calkins et al. (1998), who studied the synaptic contacts onto small bistratified ganglion cells in the same electron microscopic series.

To illustrate the number and organization of the synaptic contacts between $\mathrm{S}$ cones and S-cone ON bipolar cells, we constructed "hybrid" synaptic surfaces for the synaptic terminals of $S$ cone 35 (see Fig. $1 A$ ) and S cone 52 (see Fig. $1 B$ ), as described by Herr et al. (2003). First, from each section, we traced the contour of the presynaptic face of the $S$-cone terminal by hand onto a clear plastic sheet (Herr et al., 2003, compare their Fig. 5). The synaptic face was bounded by Müller cell contacts (Burris et al., 2002). Second, we removed the parts of the terminal membrane over invaginating lateral elements and replaced those parts with the regions of apposition between lateral elements and the tips of invaginating central elements (Herr et al., 2003, compare their Fig. 5). This operation created a hybrid contour, comprised mainly of

cone to OFF midget bipolar cell to OFF midget ganglion cell (Klug et al., 2003). Thus, identification of S-cone-specific circuits through the retina seemed complete.

However, additional quantitative study of the S-cone ON circuitry in monkey fovea revealed a puzzling feature. For each $S$ cone, there are two S-cone ON bipolar cells and two BY ganglion cells (Herr et al., 2003). This finding seemed to violate general principles of retinal wiring: (1) many receptors converge onto fewer bipolar cells and still fewer ganglion cells; and (2) ganglion cells of a given type approximately "tile" the receptor surface but avoid oversampling (Wässle and Boycott, 1991). Here, we quantify synaptic connections across the three-tiered mosaic and calculate the strength of S-cone connections to BY ganglion cells. (presynaptic) terminal membrane but partly of the (postsynaptic) tips of central elements. Third, to create a three-dimensional data set, the tracings of all the hybrid contours were superimposed, aligned, and digitized into the Montage program (Smith, 1987). Fourth, we tiled the threedimensional data sets with the Contour Filter program (Meyers et al., 1992). Finally, we produced stereo visualizations of the hybrid surface of each S-cone terminal with the Geomview package from the Geometry Center, University of Minnesota (http://www.geomview.org/), and the Blue Moon Rendering Tools (NVIDIA, Santa Clara, CA).

In these visualizations (see Fig. 1), colored patches represent the regions of synaptic contact between the S-cone terminal and the central elements provided by its S-cone ON bipolar cells. Each patch comprises the (postsynaptic) tip of the central element and the adjacent (presynap- 


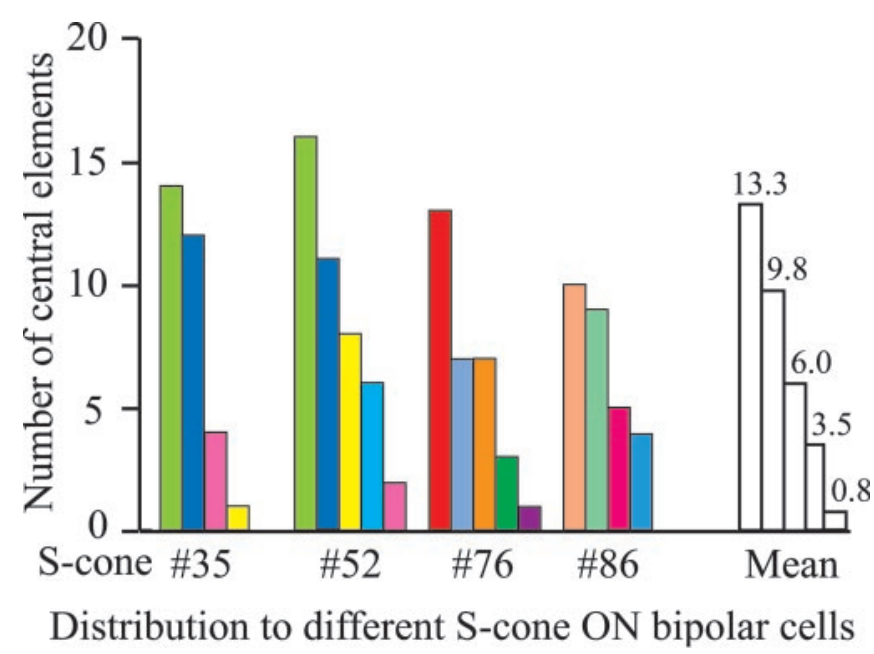

Figure 2. An $S$ cone distributes its output to $\sim 30$ bipolar cell dendrites but does so unequally, in numbers that are $\sim 12,9,6$, and 3 . Each $S$-cone terminal supplied numbers of ribbon synapses that are shown by the colored bars to different $\mathrm{S}$-cone $0 \mathrm{~N}$ bipolar cells (Herr et al., 2003, their Table 2A). The coloring of the bars in the histograms for S-cone terminals 35 and 52 follows the coloring of the contacts made by each $\mathrm{S}$-cone $0 \mathrm{~N}$ bipolar cell with those terminals in Figure 1. The numbers of synapses are arranged from largest to smallest, revealing a step-like pattern for each $S$ cone. The mean of the total number of synapses is 33.3 central elements.

tic) area of apposition between the S-cone terminal membrane and the central element. Each color is associated with a different S-cone ON bipolar cell.

Foveal ON diffuse bipolar cells make many triad-associated basal contacts as well as provide central elements to their presynaptic cones (Hopkins and Boycott, 1995, 1996, 1997; Calkins et al., 1996). S-cone ON bipolar cells also make triad-associated contacts with $S$ cones (Kolb et al., 1997), but very few of them. We identified and counted these triad-associated contacts with just one S-cone terminal, the one shown in Figure $1 \mathrm{~B}$. In that figure, the orange patches represent triad-associated contacts.

\section{Results}

Each $S$ cone contacts several S-cone $\mathrm{ON}$ bipolar cells at many sites

The region of retina that we studied contained the synaptic terminals of six S cones, of which four $(35,52,76$, and 86$)$ were completely within the series of electron micrographs. The synaptic face of terminal 35 (Fig. $1 A$ ) showed 22 synaptic ribbons. Two of these had two ribbon synaptic units each and hence two active zones each (Chun et al., 1996; Migdale et al., 2003), giving a total of 24 active zones. Sixteen active zones made a ribbon synapse with a single central element, six active zones made ribbon synapses with two central elements, and two active zones made ribbon synapses with three central elements. In three cases, two active zones shared a central element. Thus, the total number of central elements postsynaptic to ribbon synapses was $31=(16 \times$ $1)+(6 \times 2)+(2 \times 3)-(3 \times 1)$.

These 31 central elements were provided by four S-cone ON bipolar cells (details below). In general, if an active zone made ribbon synapses with more than one central element, those central elements were provided by different S-cone ON bipolar cells (Herr et al., 2003). The only exception in this terminal was active zone 5, where two of the three central elements came from the same bipolar cell. Thus, apart from an occasional exception, the rule is that each central element of an S-cone ON bipolar cell samples a different active zone.

The synaptic face of terminal 52 showed 23 synaptic ribbons that formed 25 active zones and contacted 43 central elements from five S-cone ON bipolar cells (Fig. 1 B) (Herr et al., 2003). For
A

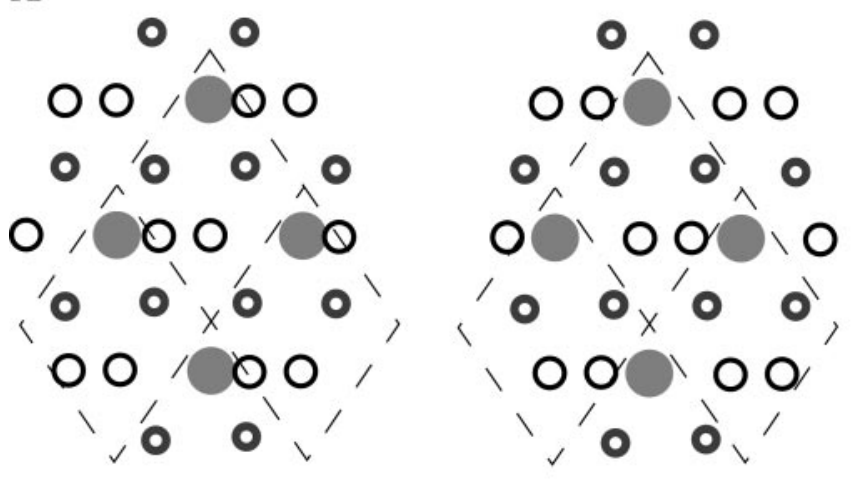

B

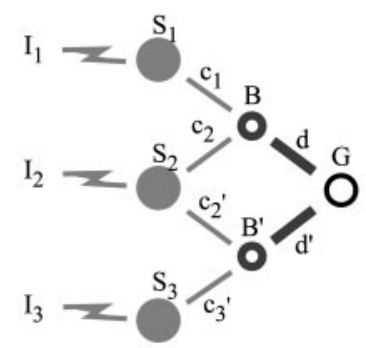
Light intensities $\mathrm{I}_{1}, \mathrm{I}_{2}, \mathrm{I}_{3}$
$\mathrm{S}$ cones $\mathrm{S}_{1}, \mathrm{~S}_{2}, \mathrm{~S}_{3}$
Numbers $\left(\mathrm{c}_{1}, \mathrm{c}_{2}, \mathrm{c}_{2^{2}}, \mathrm{c}_{3^{\prime}}\right)$ of ribbon synapses from cone to bipolar central processes
- S-cone ON bipolar cells B and B'
- Numbers ( $\mathrm{d}$ and $\mathrm{d}^{\prime}$ ) of ribbon synapses from S-cone ON bipolar cells to BY ganglion cell
BY ganglion cell G

Figure 3. Relative cell densities (1:2:2) and calculation of synaptic weight. $A$, For each $S$ cone, in the outermost layer of the retina, two $\mathrm{S}$-cone $\mathrm{ON}$ bipolar cells are in the middle layer, and two BY ganglion cells are in the innermost layer. This stereo figure synthesizes data from Herr et al. (2003) and Calkins et al. (1998). Each dashed diamond houses one S cone, two S-cone ON bipolar cells, and two BY ganglion cells. The stereo view makes it easier to see the actual arrangement that is being represented by the symbols: $S$ cones are in the outermost layer in the neural retina, the bipolar cells are in a middle layer, and the ganglion cells are in the innermost layer. To see the surfaces in depth, readers should cross their eyes. B, Because BY ganglion cells are linear, synaptic weights may be calculated as the product of the number of $S$-cone ribbon synapses onto $\mathrm{S}$-cone $\mathrm{ON}$ bipolar cells and the number of bipolar ribbon synapses onto BY ganglion cells. The proof of this assertion is presented in Appendix.

this terminal, we extended previous results (Herr et al., 2003) by identifying triad-associated, basal contacts. The synaptic face made a few (five) such contacts onto four S-cone ON bipolar cells (Fig. $1 B$, orange contacts). Our present analysis mostly ignores these contacts with noncentral elements, but we show later that including them does not change the main findings or conclusions.

Each S-cone terminal in our series contacted four or five $\mathrm{S}$-cone $\mathrm{ON}$ bipolar cells and made ribbon synapses with an average of 33 central elements (Fig. 2). The output of an S-cone was not distributed equally among its S-cone ON bipolar cells. When we arranged the numbers of outputs to these bipolar cells in descending order, they approximately fit the ratio 12:9:6:3, and we used this simple ratio in the initial calculations. No S-cone ON bipolar cell received the majority of its input from a single $\mathrm{S}$ cone.

\section{Connectivity across the three-tiered mosaic}

The S-cone array overlies an array of S-cone ON bipolar cells, the density of which is twice that of $S$ cones, and the array of bipolar cells overlies an array of BY ganglion cells, the density of which is also twice that of S cones (Fig. $3 A$ ). The physiological effects of S cones on the BY ganglion cell are linear (Chichilnisky and Baylor, 1999). Based on this finding, we computed the overall weight of an $\mathrm{S}$ cone on a BY ganglion cell: (number of ribbon synapses from $S$ cone to its bipolar cells $) \times($ number of ribbon synapses between 


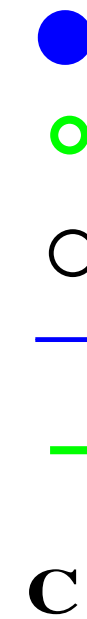

$\mathrm{S}$ cone

S-cone ON

bipolar cell

BY ganglion cell

3 ribbon synapses from $\mathrm{S}$ cone to S-cone ON bipolar cell

- 14 ribbon synapses from bipolar cell to BY ganglion cell

C

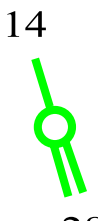

S-cone ON bipolar cell diverges to $2 \mathrm{BY}$ ganglion cells

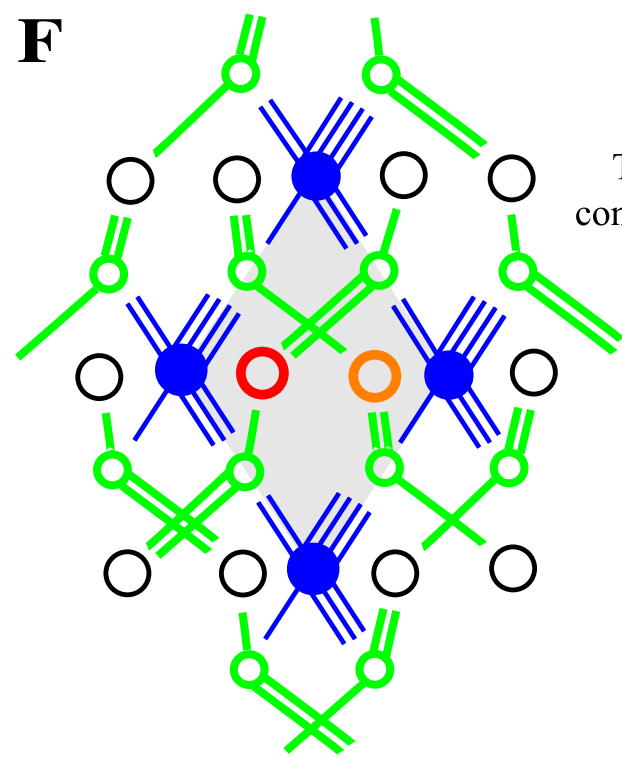

Each BY ganglion cell collects from 2 bipolar cells that share no $\mathrm{S}$ cone
A

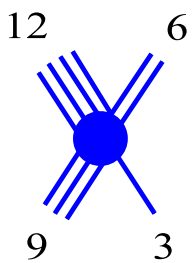

S-cone diverges to $4 \mathrm{~S}$-cone ON bipolar cells

D

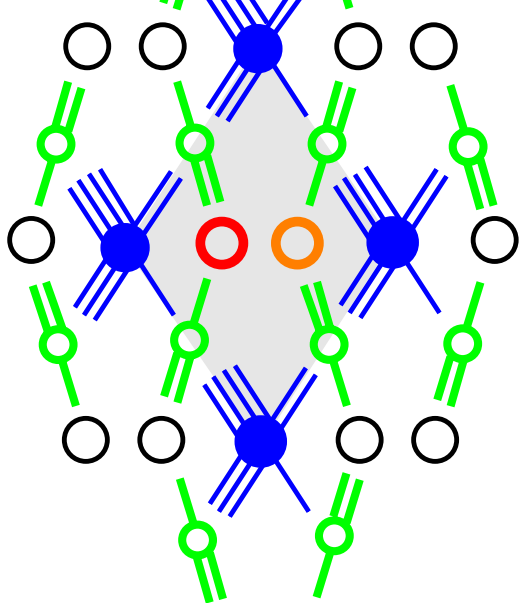

Two S-cone ON bipolar cells converge on each BY ganglion cell

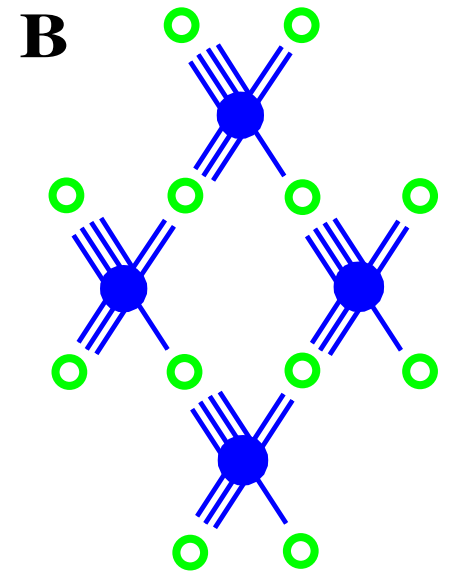

Two $\mathrm{S}$ cones converge on each S-cone ON bipolar cell

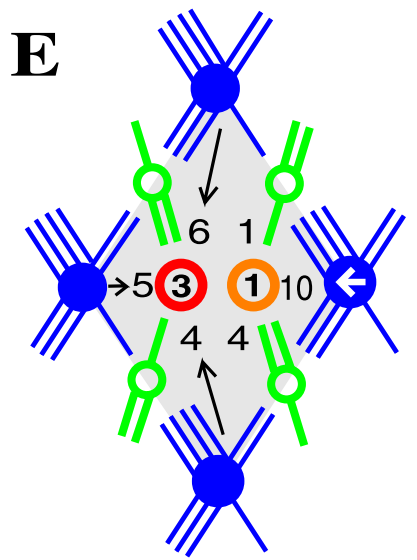

Synaptic weights of $3 \mathrm{~S}$ cones onto each BY ganglion celll

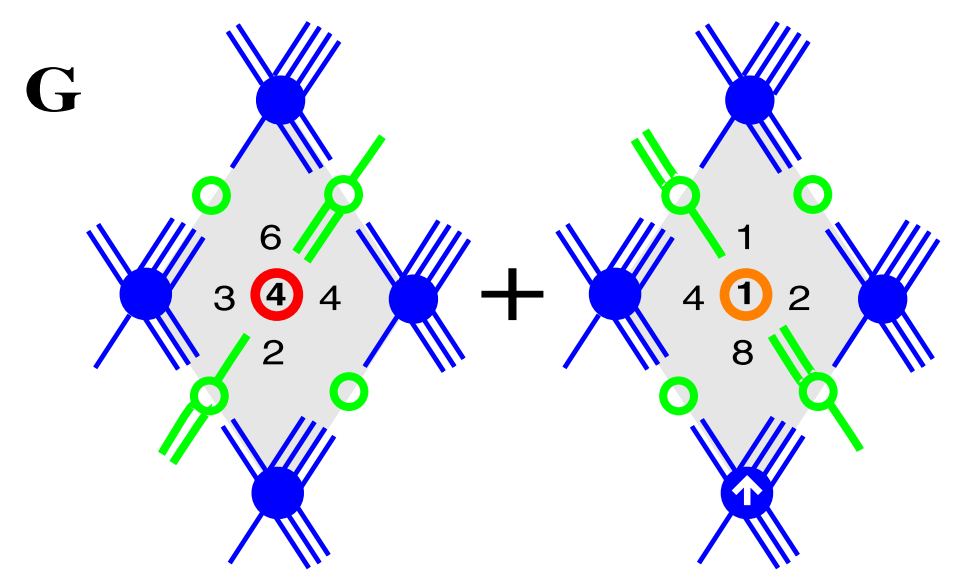

Synaptic weights of $4 \mathrm{~S}$ cones onto each BY ganglion cell

Figure 4. Circuit connecting an idealized S-cone array to BY ganglion cells. A, Each S-cone terminal makes ribbon synapses with four S-cone 0N bipolar cells, which contribute 3, 6, 9, and 12 central elements. Each blue bond represents three ribbon synapses or central elements, so we can represent the numbers of central elements by a single blue bond, a double blue bond, a triple blue bond, and a quadruple blue bond. $B$, Each $S$-cone $0 \mathrm{~N}$ bipolar cell receives its input via a total of 15 central elements that it provides to two $S$-cone terminals, either 6 and 9 central elements (a double blue bond and a triple blue bond) or 3 and 12 central elements (a single blue bond and a quadruple blue bond). The real average total is 16.2 central elements (Herr et al., 2003). C, Each S-cone 0N bipolar cell provides an output of 42 ribbon synapses to BY ganglion cells, one-third (or 14) to one ganglion cell and two-thirds (or 28) to a second. A green bond represents 14 ribbon synapses, so we represent 14 and 28 ribbon synapses by a single green bond and by a double green bond. D, Each idealized BY ganglion cell receives a total of 42 ribbon synapses, one-third (a single green bond) from one S-cone ON bipolar cell and two-thirds (a double green bond) from a second, and these two $\mathrm{S}$-cone $0 \mathrm{~N}$ bipolar cells have an $\mathrm{S}$ cone in common. In this connectivity scheme, each ganglion cell is driven by three $S$ cones. $E$, Three numbers are around each BY ganglion cell. Each number points from one $S$ cone and represents the synaptic weight from that $S$ cone, calculated as described in Results. The number 1 inside the (orange) ganglion cell on the right indicates that it is dominated by one $S$ cone; correspondingly, the arrow in the east $S$ cone points to the (orange) ganglion cell that it dominates. The number 3 inside the ganglion cell on the left indicates that it has three principal $S$ cones. $F$, Each BY ganglion cell receives input from two S-cone $0 \mathrm{~N}$ bipolar cells, but these two bipolar cells have no $S$ cone in common. In this scheme, each ganglion cell is driven by four $S$ cones. $G$, The synaptic weights are calculated as in $E$. To have enough space to show the numbers representing synaptic weights, the figure is in two parts, one for each of the two ganglion cells in the diamond in $F$. 
these bipolar cells and the BY ganglion cell) (Fig. 3B) (see proof in Appendix).

We used the known density ratios (1:2:2), this method of calculating synaptic weights, and the slightly idealized numbers of cone outputs (12:9:6:3) to calculate synaptic weights of an array of $\mathrm{S}$ cones onto an array of BY ganglion cells. Figure 4 moves stepwise through the basic reasoning and key conclusions. Figure $4 \mathrm{~A}$ shows an $\mathrm{S}$ cone with blue bonds that indicate the number of ribbon synapses that it makes with central elements. Following the step-like distribution in Figure 2, we have simplified the numbers of central elements provided by its four target S-cone ON bipolar cells to idealized numbers $12,9,6$, and 3 . If each blue bond represents three central elements, each idealized $S$ cone makes a quadruple, a triple, a double, and a single blue bond. The total of 10 blue bonds corresponds to 30 central elements. Idealized $\mathrm{S}$ cones thus represent real data rather closely.

Our data show that each S-cone ON bipolar cell provides an average total of 16.8 central elements to its two $S$ cones (Herr et al., 2003). Figure $4 B$ shows two kinds of idealized S-cone ON bipolar cell. One makes a double blue bond (six central elements) with one S cone and a triple blue bond (nine central elements) with another. The total of 15 central elements resembles the actual average. The other idealized bipolar cell makes a single blue bond ( 3 central elements) and a quadruple blue bond (12 central elements) with its two $\mathrm{S}$ cones, also a total of 15 central elements.

From investigation of the same foveal series of sections that provided the data for Herr et al. (2003) and the present study, Calkins et al. (1998) reported reconstruction of two BY ganglion cells. One received $71 \%$ of its ribbon synapses from one S-cone ON bipolar cell and 29\% from another; the other received 65,25 , and $10 \%$ from three S-cone ON bipolar cells. The average values are 68,27 , and $5 \%$. For modeling purposes, we assume that twothirds (67\%) of the ribbon synapses onto a BY ganglion cell are provided by one S-cone ON bipolar cell and one-third (33\%) is provided by a second.

Because the number of S-cone ON bipolar cells and the number of BY ganglion cells are the same (Herr et al., 2003), each S-cone ON bipolar cell in turn provides ribbon synapses to just two BY ganglion cells. In addition, Calkins et al. (1998) found that the axon terminal of an S-cone ON bipolar cell provided $\sim 42$ ribbon synapses. Therefore, in Figure 4C, we represent the output of an S-cone ON bipolar cell with one-third ( $n=14$ ) of its ribbon synapses by a single green bond and two-thirds $(n=28)$ of its ribbon synapses by a double green bond.

Correspondingly, in Figure $4 D$, we show each idealized BY ganglion cell receiving a total of 42 ribbon synapses from two S-cone ON bipolar cells, 28 (a double green bond) from one bipolar cell and 14 (a single green bond) from the other bipolar cell. In this connectivity scheme, each ganglion cell is driven by three $S$ cones.

Because BY ganglion cells linearly combine signals from different S cones (Chichilnisky and Baylor, 1999), we could determine the synaptic weight from a particular $\mathrm{S}$ cone onto a BY ganglion cell as the product of the number of ribbon synapses from cone to bipolar cell (represented by the number of blue bonds from cone to bipolar cell) and the number of ribbon synapses from bipolar cell to ganglion cell (represented by the number of green bonds). A formal justification for this method is given in Appendix.

The synaptic weights so computed for the connectivity scheme in Figure $4 D$ are shown in Figure $4 E$, in which each of the two ganglion cells is surrounded by three numbers that "point" from specific $\mathrm{S}$ cones. Thus, the north $\mathrm{S}$ cone in Figure $4 E$ pro- vides a synaptic weight of 6 to the (red) BY ganglion cell on the left, the product of three blue bonds from the north $\mathrm{S}$ cone to the top left bipolar cell and two green bonds from that bipolar cell to the red ganglion cell. The synaptic weight of the south $S$ cone to the red ganglion cell is 4 , the product of four blue bonds and one green bond. For an $\mathrm{S}$ cone that contributes via two S-cone ON bipolar cells, the weight is the sum of the weights along each pathway. Thus, the west $S$ cone has a weight of 5 onto the red ganglion cell, the sum of the weights through the two S-cone ON bipolar cells on the left: $(2 \times 2)+(1 \times 1)$. The same method gives weights of 10,4 , and 1 for the three $S$ cones supplying the (orange) $\mathrm{BY}$ ganglion cell on the right.

The orange BY ganglion cell in Figure $4 E$, with synaptic weights 10,4 , and 1 , appears to be dominated by one $S$ cone (the one to the east), whereas the red ganglion cell, with synaptic weights 6,5 , and 4 , appears to be diffusely driven by its three $S$ cones. To formalize these impressions, we first sort the synaptic weights and assign S1 to be the greatest (e.g., 10), S2 the intermediate (e.g., 4), and S3 the lowest (e.g., 1). If the greatest weight S1 is at least twice as great as the intermediate weight $\mathrm{S} 2$, we say that the ganglion cell is dominated by one $\mathrm{S}$ cone. If that is not the case, but the intermediate weight $\mathrm{S} 2$ is at least twice as great as the lowest weight $\mathrm{S} 3$, we say that the ganglion cells has two principal $\mathrm{S}$ cones. If that is not the case, we say the ganglion cell has three principal $S$ cones.

Therefore, the orange ganglion cell in Figure $4 E$, with weights 10,4 , and 1 , is formally dominated by one $S$ cone, which we indicate by the number 1 inside the ganglion-cell symbol. In addition, an arrow inside the S-cone symbol with weight 10 points to the (orange) ganglion cell that it dominates. In contrast, the red ganglion cell in Figure $4 E$, with weights 6, 5, and 4, has three principal $S$ cones, indicated by the number 3 inside the ganglioncell symbol.

A BY ganglion cell may be driven by four $S$ cones, two via one $\mathrm{S}$-cone ON bipolar cell and two different ones via a second S-cone ON bipolar cell (Fig. 4F). The synaptic weights are illustrated in Figure $4 G$, which shows two diamonds, each with one of the two ganglion cells contacted by the same four $\mathrm{S}$ cones as in Figure $4 \mathrm{~F}$. In this case, the weights are sorted from highest (S1) to lowest (S4), with the "at least twice as great" rule applying similarly. Thus, the (orange) BY ganglion cell on the right in Figure $4 G$, with weights $8,4,2$, and 1 , is dominated by one $S$ cone, the one to the south. The (red) ganglion cell on the left, with weights 6, 4, 3, and 2, has four principal S cones.

To summarize: The three-tiered arrays of triangularly packed $\mathrm{S}$ cones, $\mathrm{S}$-cone ON bipolar cells, and BY ganglion cells in Figure 4, $D$ and $F$, satisfy all of the biological constraints: (1) the cell density ratios 1:2:2; (2) the contribution by each cone of 3, 6, 9, and 12 ribbon synapses; (3) the pooling by each bipolar cell of 15 ribbon synapses from two S cones; (4) the contribution by each bipolar cell of 14 ribbon synapses to one ganglion cell and 28 ribbon synapses to another; and (5) pooling by each BY ganglion cell of 42 ribbon synapses $(14+28)$. These two examples lead to a surprising hypothesis: one of every two BY ganglion cells is dominated by a single $S$ cone, whereas the other is diffusely driven by several $\mathrm{S}$ cones. We examined this hypothesis in detail.

\section{The unit of connectivity shows a standard pattern}

To directly test the hypothesis that for every $\mathrm{S}$ cone there is one private and one "diffuse" BY ganglion cell would require reconstruction of the three-dimensional circuit across a broad patch of retina. Such a reconstruction project would reveal many repetitions of the circuit and thus establish exactly which features vary 

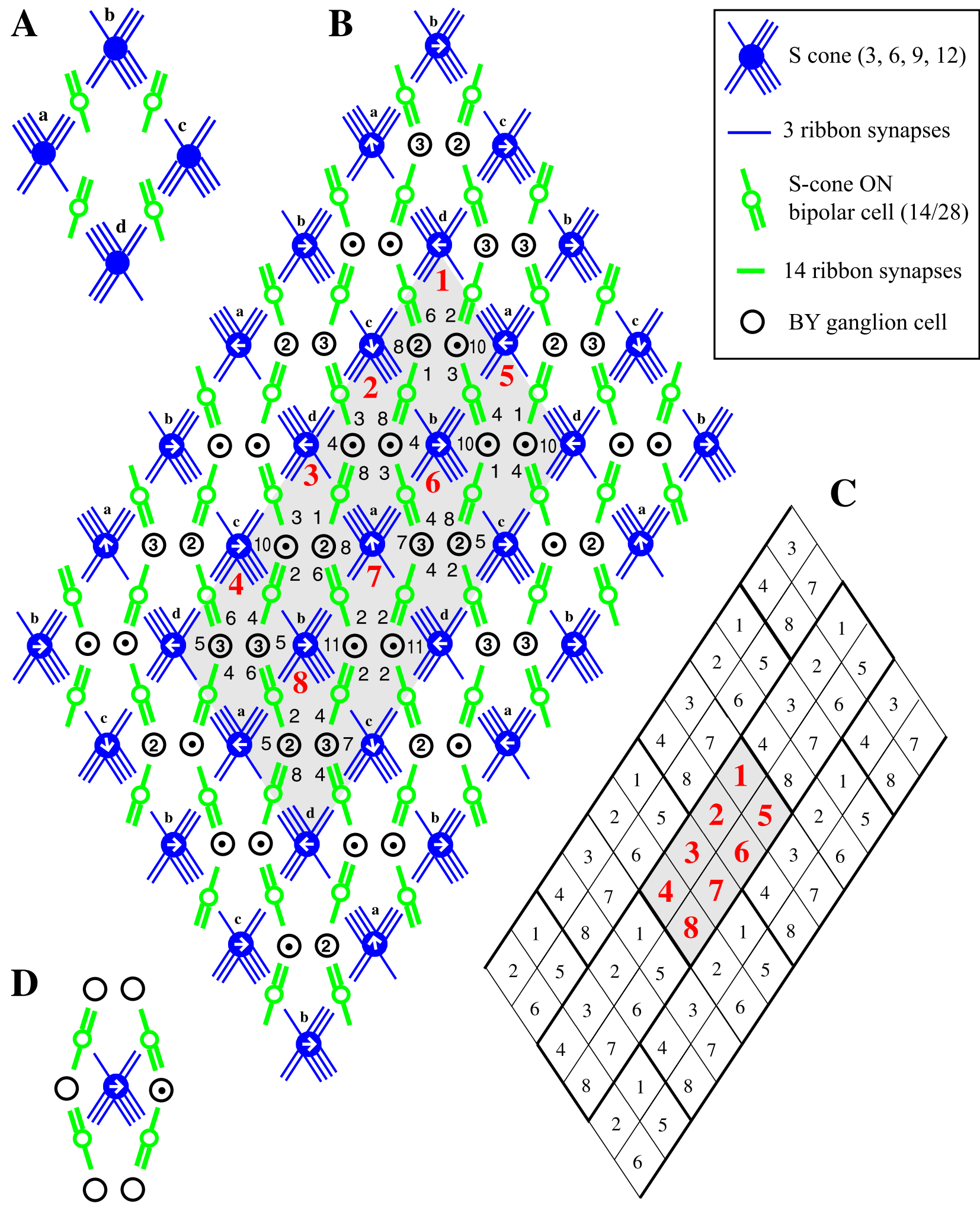

Figure 5. A standard pattern is generated by a model that uses densities of each cell type and typical patterns of divergence and convergence to capture the unit of connectivity across the three-tiered mosaic, a tile that repeats across the retina to generate the complete connectivity. $A$, Each $S$ cone diverges to four $S$-cone $0 \mathrm{~N}$ bipolar cells, distributing its $\sim 30$ ribbon synapses in the ratio 3:6:9:12, represented by 1, 2, 3, and 4 blue bonds. Two $S$ cones converge on each bipolar cell. The $S$-cone bonds, in four configurations (a-d), are arranged so that single blue bonds are opposite quadruple blue bonds, and double blue bonds are opposite triple blue bonds, permitting each S-cone ON bipolar cell to collect five blue bonds, representing 15 ribbon synapses. Each S-cone $0 \mathrm{~N}$ bipolar cell diverges to two BY ganglion cells, distributing 14 ribbon synapses (single green bond) to one ganglion cell and 28 (double green bond) to the other. $B$, From the patterns of divergence and convergence at each level, plus the cell densities at each level (Fig. 3), we derive a unit of connectivity (large, gray diamond). It includes 16 ganglion cells in pairs within eight smaller diamonds. The standard pattern emerges: half of the ganglion cells are dominated by one $S$ cone, half by more than one $S$ cone, and each $S$ cone dominates a single BY ganglion cell but contributes to several others. C, The large gray diamond in B, containing eight small diamonds (1-8), represents the unit of connectivity that repeats in larger arrays. A complete set thus includes the eight pairs of BY ganglion cells, the synaptic weights of which are shown in $B$, and eight $S$ cones, one (the north one, for example) from each of the eight small diamonds. $D$, The model ( $B$ ) establishes that each $S$ cone diverges to six BY ganglion cells, dominating one of the six and contributing to the other five. 
and how that variation would affect the conclusion. Because the detail gathered here required 319 serial, thin sections and $\sim 10,000$ electron micrographs, it seemed impractical to repeat reconstruction over the much larger region. Instead, we used the identified biological constraints to construct a "unit of connectivity" (Fig. 5, large gray diamond). Then, we relaxed several constraints in this pattern and tested the effect on the main conclusions (see Figs. 6-8).

Figure $5 A$ shows four possible configurations $(a-d)$ of the ribbon synaptic output from an S-cone terminal. The array in Figure $5 B$, which uses an equal mixture of the four configurations, has exactly eight different types of small diamond, four attributable to the different configurations of the cone synapses and four again attributable to a second pattern of synapses (single and double green bonds) from bipolar cells to ganglion cells. The eight small diamonds with red numbers $1-8$ (Fig. $5 B$ ) repeat in larger patterns (Fig. $5 C$ ), so to characterize the whole array, one need only examine synaptic weights for one set of eight small diamonds. This set of eight small diamonds, marked by the large gray diamond in Figure 5, $B$ and $C$, thus represents the unit of connectivity for these constraints.

As shown in Figure 5B, 8 of the 16 ganglion cells in this unit are dominated by a single $S$ cone, with weights of $8-11$. These ganglion cells are marked with a dot inside their symbol instead of a 1 to make it easy to partition the singly dominated ganglion cells from the others. The other eight ganglion cells, the ones with the number 2 or 3 inside their symbol, have two or three principal S cones with weights of $1-7$.

In addition, every $\mathrm{S}$ cone in this array dominates one BY ganglion cell, and each $S$ cone in Figure $5 B$ is shown with an arrow pointing toward the ganglion cell that it dominates. However, every $\mathrm{S}$ cone contributes to the activity of a total of six BY ganglion cells (Fig. 5D): it dominates one of the six, two other $\mathrm{S}$ cones dominate another two of the six, and each of the remaining three ganglion cells has two or three principal $S$ cones.

Within each small diamond in Figure $5 B$, both ganglion cells may be dominated by one $\mathrm{S}$ cone or may be more diffusely driven, but from the perspective of the $\mathrm{S}$ cone, the precise arrangement of the ganglion cell somas is unimportant. The key point is that every $\mathrm{S}$ cone manages to establish a private pathway to the brain while also contributing to several shared pathways.

We refer to this pattern of results as the "standard pattern": half of the BY ganglion cells are dominated by one $\mathrm{S}$ cone, and half have more than one principal S cone; moreover, every S cone dominates exactly one BY ganglion cell but contributes to several others. In arrays with other configurations of S cones ( $a, b, c$, or d alone; or combinations of $\mathrm{a}$ and $\mathrm{c}$ or $\mathrm{b}$ and $\mathrm{d}$ ), the standard pattern still holds (data not shown).

As described above, a blue bond from cone to bipolar cell represents 3 ribbon synapses, and a green bond from bipolar cell to ganglion cell represents 14 ribbon synapses. Thus, for example, the synaptic weight from a particular $\mathrm{S}$ cone to a BY ganglion cell of four ( 2 blue bonds $\times 2$ green bonds) in Figure $4 E$ represents 28 samples $(2 \times 14$ ribbon synapses $)$ of the activity of the bipolar cell, which itself receives six samples $(2 \times 3$ central elements $)$ of the activity of the $S$ cone. The synaptic weight thus corresponds to $2 \times 14 \times 2 \times 3=168$ samples of the activity in the $\mathrm{S}$ cone, a mechanism that gives the ganglion cell a statistically accurate measurement of the activity in the $\mathrm{S}$ cone. By these calculations, the same weight would be achieved with one green bond from the bipolar cell to the ganglion cell $(1 \times 14$ samples $)$ and four blue bonds from an $\mathrm{S}$ cone to a bipolar cell $(4 \times 3$ samples $)$, giving the same number $4 \times 3 \times 1 \times 14=168$ samples of the activity in the S cone.

\section{The two-thirds/one-third constraint on the bipolar synaptic output is not critical}

As discussed, the claim that an S-cone ON bipolar cell makes two-thirds of its 42 synapses with one BY ganglion cell and onethird with a second cell rests on data from just two BY ganglion cells (Calkins et al., 1998). To test whether this constraint is critical for the main conclusions, we constructed a unit of connectivity assuming that each bipolar cell provides half of its synapses to one ganglion cell and half to the other (Fig. 6A). All the other constraints were the same as before.

Four small diamonds, with four pair of ganglion cells, represent a complete set that repeats in larger arrays. The standard pattern holds (Fig. 6A), with four of eight ganglion cells dominated by one $S$ cone (weights $7,2,1$ and $6,3,1$ ), two with two principal $S$ cones $(4,4,2)$, and two with three principal $S$ cones (4, $3,3)$; moreover, every $\mathrm{S}$ cone dominates exactly one BY ganglion cell. In arrays with other configurations of $S$ cones ( $a, b, c$, or d; or combinations of two of those), the standard pattern still holds (data not shown). Therefore, the one-third/two-thirds constraint is not critical.

\section{Ganglion cell circuits based on four $S$ cones also show the standard pattern}

The two bipolar cells that contact each ganglion cell could share no $\mathrm{S}$ cone. In that case, each ganglion cell is driven by four $\mathrm{S}$ cones (Fig. 4F). We tested whether this connectivity would affect the main hypothesis. Following Figure $4 G$, the array at the top of Figure $6 B$ shows one pair of ganglion cells of each diamond, and the array at the bottom shows the other ganglion cell of the pair. Four diamonds, with four pair of ganglion cells, represent a complete set that repeats in larger arrays, so synaptic weights are shown only for the eight ganglion cells in that unit of connectivity. As shown in the top array, one of the two ganglion cells in each diamond is dominated by one $S$ cone (weights $8,4,2,1$ ), and each $\mathrm{S}$ cone dominates one ganglion cell. As shown in the bottom array, the other ganglion cell in each pair collects from four $S$ cones $(6,4,3,2)$. Thus, each $\mathrm{S}$ cone dominates just one ganglion cell, but it contributes to eight. In short, but for minor details, the standard pattern holds.

\section{Arrays based on real S cones also show the standard pattern}

The models so far were constructed with slightly idealized numbers $12,9,6$, and 3 of S-cone outputs, so we tested whether the actual numbers would affect the standard pattern. The arrays in Figure 7 comprise a mixture of all four real S-cone terminals. As shown in Figure $7 A, \mathrm{~S}$ cone 86 occupies the "a" position, 76 the "b," 35 the "c," and 52 the "d." These positions most closely resemble their actual configuration in our patch of foveal retina (Herr et al., 2003, compare their Fig. 2).

The array in Figure $7 B$ assumes (1) three $S$ cones drive each ganglion cell, (2) each bipolar cell provides 14 and 28 synapses, and (3) each ganglion cell collects 42 synapses (14 and 28 from two bipolar cells). S cones are still shown with multiple blue bonds, but here they represent the actual numbers of synapses onto central elements specified for each $\mathrm{S}$ cone in Figure $7 A$. The quadruple bond represents the highest number of ribbon synapses from that $S$ cone, the triple bond represents the next highest number, and so on. Correspondingly, synaptic weights are not computed as the product of the number of blue and green bonds but rather as the product of the actual numbers of S-cone ribbon 

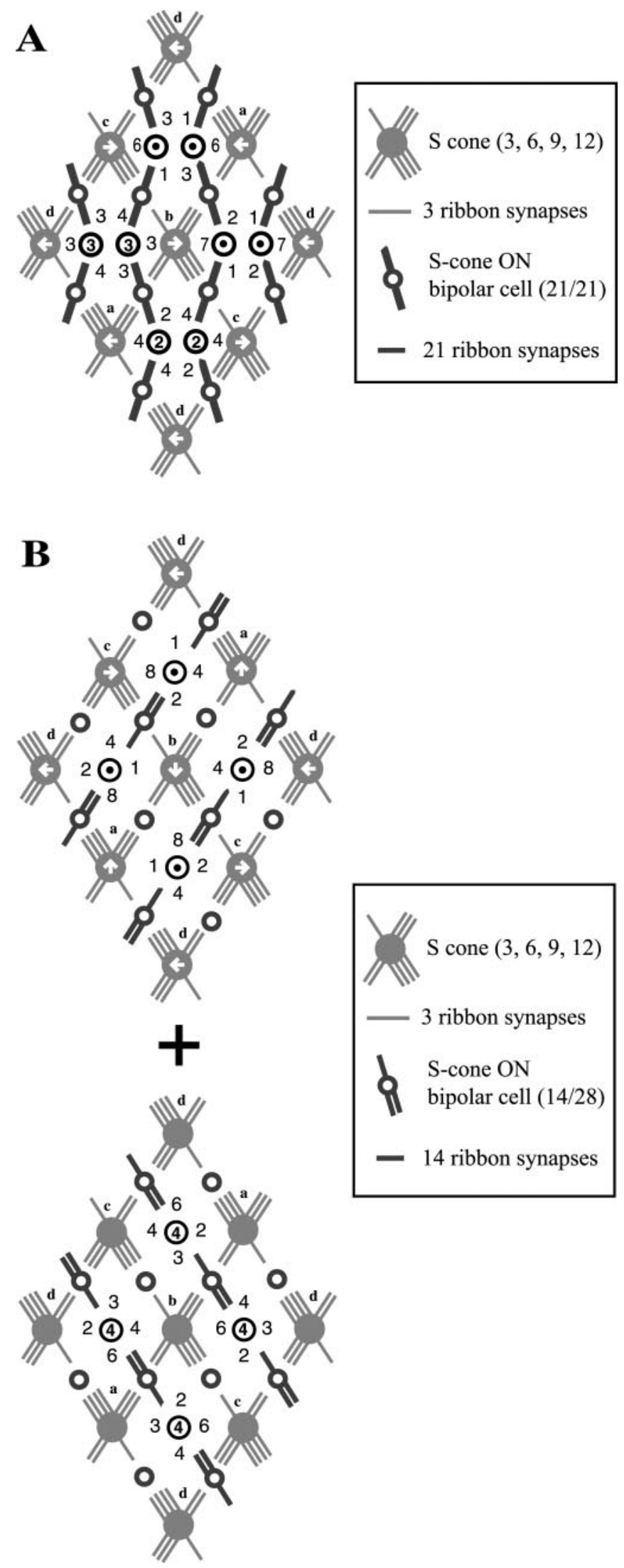

Figure 6. The standard pattern is independent of the partitioning of synapses between cones and bipolar cells and between bipolar cells and BY ganglion cells. A, Synaptic weights for an array of idealized $S$ cones like that in Figure 5, except that S-cone $0 \mathrm{~N}$ bipolar cells and BY ganglion cells are connected by single green bonds, each representing 21 ribbon synapses. Four small diamonds, with four pairs of ganglion cells and four $S$ cones, represent a unit of connec- synapses and green bonds. Seven of the 16 ganglion cells are dominated by one $S$ cone, and seven of the eight $S$ cones dominate one ganglion cell (Table 1 , mix). These results closely resemble the standard pattern, constructed from the arrays with idealized $\mathrm{S}$ cones (Fig. 5B; Table 1, idealized).

The array in Figure $7 C$, also comprising a mixture of four real $\mathrm{S}$-cone terminals, assumes that three $\mathrm{S}$ cones drive each ganglion cell and the 21/21 condition (Table 2, mix). These results are also close to the standard pattern (Fig. 5C; Table 2, idealized). Thus, the standard pattern of results holds for real $S$ cones as well as for idealized S cones and does not depend on the two-thirds/onethird partitioning of bipolar ribbon synapses to BY ganglion cells.

\section{Including triad-associated contacts does not change the model}

$\mathrm{S}$ cones contact S-cone ON bipolar cells at triad-associated contact sites as well as at central elements, and we considered whether including these contacts would alter the model. First, we counted numbers of triad-associated contacts made by cone terminal 52 (Fig. $1 B$ ). Then, we created an array like that in Figure $7 B$, but with all four positions ( $\mathrm{a}, \mathrm{b}, \mathrm{c}$, and $\mathrm{d}$ ) occupied by $\mathrm{S}$-cone terminal 52 , that contacts 16, 11, 8, and 6 central elements. Finally, we created a similar array with S-cone terminal $52^{\star}$, that makes 17 , 13, 9, and 7 synaptic contacts (central elements plus triadassociated contacts). Assuming that each bipolar cell partitions its output as 14/28 in the two arrays (as in Fig. 7B), the same number (eight) of 16 ganglion cells were dominated by one $S$ cone, and the same number (six) of eight $S$ cones each dominated at least one ganglion cell, resembling the standard pattern.

Alternatively, if bipolar cells partitioned their outputs $21 / 21$ as in Figure 7C in both arrays, the one based on S-cone terminal 52 and the other on $52^{\star}$, the same number (four) of eight ganglion cells were dominated by one $\mathrm{S}$ cone, and all four $\mathrm{S}$ cones dominated one ganglion cell, exactly replicating the standard pattern. Thus, including numbers of triad-associated contacts did not alter the basic model.

\section{Random numbers of central elements give almost the standard pattern}

Our first analysis (Fig. 5) idealized the S-cone output as a steplike distribution of synapses $(3,6,9$, and 12) and assumed that each S-cone ON bipolar cell received the largest and smallest numbers ( 12 and 3 ) or the two intermediate numbers ( 9 and 6 ) of inputs, thus equalizing their total numbers of inputs at 15 (Fig. $5 A, B$ ). Our second analysis (Fig. 7) used actual numbers of $\mathrm{S}$-cone outputs and similarly assumed that each S-cone ON bipolar cell received the largest and smallest numbers or the two intermediate numbers of inputs. Although the findings of the latter analysis, summarized as the standard pattern, are most representative of our data, we sought to challenge the standard pattern as follows.

$\leftarrow$

tivity, a complete combinatorial set that repeats in larger arrays. Half of the eight BY ganglion cells are dominated by one $S$ cone, and every one of the four $S$ cones in the complete set dominates one BY ganglion cell. B, Synaptic weights for an array of idealized S cones like that in Figure 5, except that the two $S$-cone $0 \mathrm{~N}$ bipolar cells that activate each $B Y$ ganglion cell have no $S$ cone in common, as in Figure $4, F$ and $G$, and each ganglion cell is driven by four $S$ cones. One of the two ganglion cells in each small diamond is shown in the array at the top; the other of the two is shown in the array at the bottom. Four small diamonds, with four pairs of ganglion cells and four $S$ cones, represent a complete combinatorial set that repeats in larger arrays. Half of the eight $\mathrm{BY}$ ganglion cells are dominated by one $S$ cone, and every one of the four $S$ cones in the complete set dominates one BY ganglion cell. 

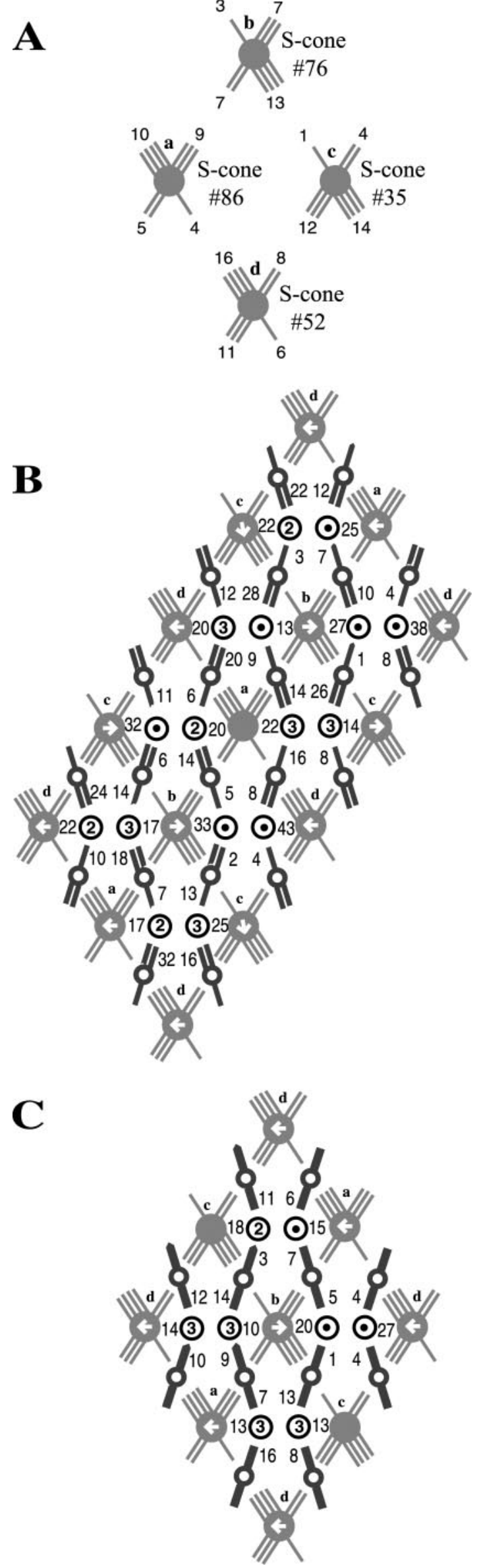

Suppose, instead, that the numbers of ribbon synapses between $\mathrm{S}$ cones and S-cone ON bipolar cells were random values from 1 to 16. [Indeed, this notion is suggested by a simple listing of the 18 numbers in Fig. $2(1,1,2,3,4,4,5,6,7,7,8,9,10,11,12$, $13,14,16)$.] We therefore investigated whether the standard pattern required the specific patterns of outputs of idealized or real $S$ cones by constructing random $S$ cones with random numbers of output from 1 to 16 to replace numbers of outputs in the four $\mathrm{S}$ cones in Figure 7A. We constructed 20 such sets of random $S$ cones.

First, we approximately balanced the total number of inputs received by each bipolar cell by assigning for each random $S$ cone the highest number of central elements to the quadruple blue bond, the second highest number to the triple blue bond, and so forth, just as we had done for the real $\mathrm{S}$ cones in Figure 7A. The rightmost distribution (large squares, heavy lines) in Figure $8 \mathrm{~A}$ shows the resulting percentage of the 16 ganglion cells that were dominated by one $\mathrm{S}$ cone over 20 random arrays like that in (approximately balanced) Figure $7 B$. On average, 7.80 of the 16 ganglion cells ( $49 \%$ ) were dominated by one $\mathrm{S}$ cone, almost identical to what was found with arrays of idealized $S$ cones $(8$ of 16 or $50 \%$ ) or arrays of a mixture of real S cones ( 7 of 16 or $44 \%$ ) (Table 1 , idealized vs mix vs random plus balanced). The rightmost distribution (large squares, heavy lines) in Figure $8 B$ shows the resulting percentage of eight $S$ cones that dominated at least one $\mathrm{S}$ cone for 20 such arrays. On average, 6.35 of the eight $\mathrm{S}$ cones (79\%) were able to dominate at least one ganglion cell, resembling the results with arrays of idealized S cones (eight of eight or $100 \%$ ) or arrays of a mixture of real S cones (seven of eight or $88 \%$ ) (Table 1).

Second, we repeated this test but avoided balancing the numbers of inputs received by the bipolar cells by randomly assigning numbers of S-cone outputs to the quadruple blue bond, the triple blue bond, and so on. The distributions in this case are also shown in Figure 8, giving an average of 5.80 of 16 ganglion cells (36\%) dominated by one $S$ cone and 4.65 of $8 \mathrm{~S}$ cones $(58 \%)$ able to dominate at least one ganglion cell (Table 1, random plus unbalanced).

Third, we tested arrays with the same 20 sets of random S-cone outputs, but with bipolar outputs partitioned 21/21 (instead of 14/28), keeping the numbers of inputs onto the bipolar cells balanced (Fig. 8). In this case, an average of 3.2 of eight ganglion cells (40\%) were dominated by one S cone (vs four of eight or $50 \%$ in arrays of idealized S cones and three of eight or 38\% in arrays of real $\mathrm{S}$ cones), and 2.8 of four $\mathrm{S}$ cones $(70 \%)$ dominated at least one ganglion cell (vs four of four or 100\% in arrays of idealized S cones and three of four or $75 \%$ in arrays of real $\mathrm{S}$ cones) (Table 2, random plus balanced).

Finally, we repeated these calculations but did not try to bal-
Figure 7. Reconstructed connections of $S$ cones and $S$-cone $\mathrm{ON}$ bipolar cells generate the standard pattern. $A$, Each of the four real $S$ cones is shown in just one $(a, b, c$, or $d$ ) configuration, and actual numbers of central elements are shown for each $S$ cone. The position of each $S$ cone in this arrangement is closest to the actual position of these $S$ cones in their patch of foveal retina (Herr et al., 2003). B, An S-cone ON bipolar cell and a BY ganglion cell are connected by a single green bond or a double green bond, representing 14 or 28 ribbon synapses, respectively. Synaptic weights are the product of the actual number of central elements, not the number of blue bonds, and the number of green bonds. Eight diamonds, with eight pairs of ganglion cells and eight $S$ cones, represent a unit of connectivity (i.e., a complete combinatorial set that repeats in larger arrays). C, An S-cone $0 \mathrm{~N}$ bipolar cell and a BY ganglion cell are connected by a single green bond, representing 21 ribbon synapses. Synaptic weights are the product of the actual number of central elements and the number of green bonds. Four diamonds, with four pairs of ganglion cells and four $S$ cones, represent a unit of connectivity that repeats in larger arrays. 
Table 1. Results for bipolar output partitioned as 14 and 28 ribbon synapses

\begin{tabular}{|c|c|c|c|c|c|c|c|c|}
\hline \multirow[b]{2}{*}{ Trial } & \multicolumn{3}{|c|}{ GCs with 1, 2, or 3 principal S cones } & \multicolumn{4}{|c|}{ S cones dominating $0,1,2$, or $3 \mathrm{GCs}$} & \multirow[b]{2}{*}{ S cones dominating $\geq 1 \mathrm{GC}$} \\
\hline & 1 & 2 & 3 & 0 & 1 & 2 & 3 & \\
\hline Idealized & $8(50 \%)$ & $4(25 \%)$ & $4(25 \%)$ & 0 & 8 & 0 & 0 & $8(100 \%)$ \\
\hline Mix & $7(44 \%)$ & $3(19 \%)$ & $6(37 \%)$ & 1 & 7 & 0 & 0 & $7(88 \%)$ \\
\hline Mean random plus balanced & $7.80(49 \%)$ & $4.25(27 \%)$ & $3.95(25 \%)$ & 1.65 & 5.20 & 0.85 & 0.30 & $6.35(79 \%)$ \\
\hline Mean random plus unbalanced & $5.80(36 \%)$ & $6.20(39 \%)$ & $4.00(25 \%)$ & 3.35 & 3.60 & 0.95 & 0.10 & $4.65(58 \%)$ \\
\hline
\end{tabular}

These results are obtained from arrays in which three $S$ cones supply input to each ganglion cell and 14 and 28 ribbon synapses connect $S$-cone $0 \mathrm{~N}$ bipolar cells and BY ganglion cells ( $G(S)$. A complete combinatorial set of ganglion cells requires eight diamonds, with 16 ganglion cells and eight $S$ cones. Idealized results are from the array with four idealized $S$ cones in Figure $5 B$. Mix results are from the array of four real $S$ cones in Figure $7 B$. Mean random plus balanced results are calculated from the data in Figure 8 for arrays like that in Figure 7B. Mean random plus unbalanced results are calculated from the data in Figure 8.

Table 2. Results for bipolar output partitioned as 21 and 21 ribbon synapses

\begin{tabular}{|c|c|c|c|c|c|c|c|}
\hline \multirow[b]{2}{*}{ Trial } & \multicolumn{3}{|c|}{ GCs with 1,2 , or 3 principal $S$ cones } & \multicolumn{3}{|c|}{ S cones dominating 0,1 , or $2 \mathrm{GCs}$} & \multirow[b]{2}{*}{ S cones dominating $\geq 1 \mathrm{GC}$} \\
\hline & 1 & 2 & 3 & 0 & 1 & 2 & \\
\hline Idealized & $4(50 \%)$ & $2(25 \%)$ & $2(25 \%)$ & 0 & 4 & 0 & $4(100 \%)$ \\
\hline Mix & $3(38 \%)$ & $1(12 \%)$ & $4(50 \%)$ & 1 & 3 & 0 & $3(75 \%)$ \\
\hline Mean random plus balanced & $3.20(40 \%)$ & $2.15(27 \%)$ & $2.65(33 \%)$ & 1.2 & 2.40 & 0.40 & $2.80(70 \%)$ \\
\hline Mean random plus unbalanced & $2.80(35 \%)$ & $2.35(29 \%)$ & $2.85(36 \%)$ & 1.70 & 1.80 & 0.50 & $2.30(58 \%)$ \\
\hline
\end{tabular}

These results are obtained from arrays in which three cones supply output to each ganglion cell (GC) and 21 and 21 ribbon synapses connect $S$-cone $0 \mathrm{~N}$ bipolar cells and BY ganglion cells. A complete combinatorial set of ganglion cells requires four diamonds, with eight ganglion cells and four $S$ cones. Idealized results are from the array with four idealized S cones in Figure $6 A$. Mix results are from the array comprising four real $S$ cones in Figure $7 C$. Mean random plus balanced results are calculated from the data in Figure 8 for arrays like that in Figure 7 . Mean random plus unbalanced results are calculated from the data in Figure 8.
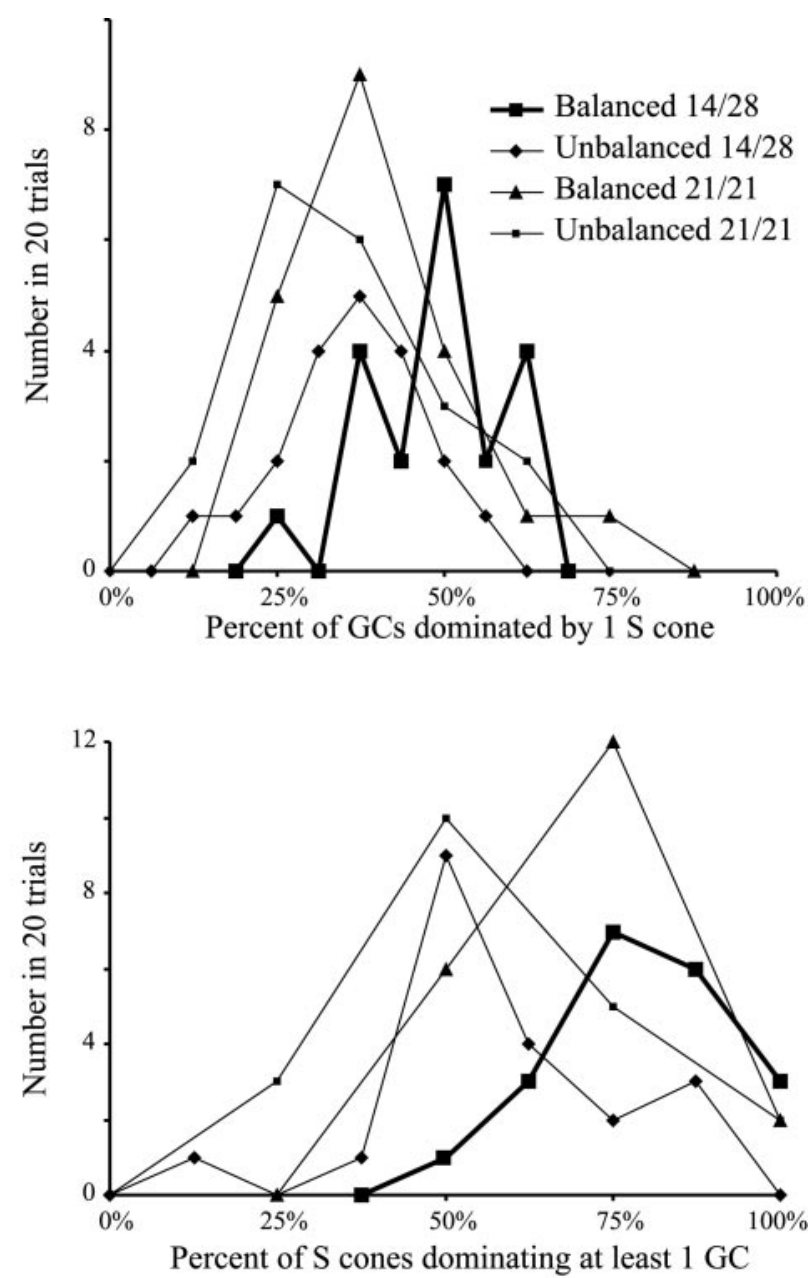

Figure 8. Random numbers of synapses between $S$ cone and bipolar cells also generate the standard pattern or close to it. A, Frequency distributions for 20 trials of the percentage of $16 \mathrm{BY}$ ganglion cells dominated by one $S$ cone. Each trial uses an array with a set of four "random $S$ cones," with each random $S$ cone presynaptic to four numbers of central elements randomly chosen among integers from 1 to 16 . Distributions are shown for four different sets of constraints that are described in Results. $B$, Frequency distributions for the same 20 trials and constraints of the percentage of eight $S$ cones that dominate at least one BY ganglion cell. ance numbers of inputs onto the bipolar cells (Fig. 8D). An average of 2.8 of eight ganglion cells (35\%) were dominated by one $\mathrm{S}$ cone, and 2.3 of four S cones $(58 \%)$ dominated at least one ganglion cell (Table 2, random plus unbalanced).

With an S-cone array with a step-like (idealized) number of outputs and exactly balanced numbers of inputs to S-cone ON bipolar cells, one-half of the ganglion cells would be dominated by one $\mathrm{S}$ cone, and all of the $\mathrm{S}$ cones would each dominate one ganglion cell (i.e., the standard pattern emerges) (Fig. 5). With data from real cones (Fig. 7) or even from cones with random numbers of outputs but with bipolar cells receiving approximately balanced numbers of inputs, the values are almost the same (Table 1). Under conditions in which the number of inputs received by the bipolar cells is not kept balanced, the values decline. However, even in the worst case, one-third instead of onehalf of the ganglion cells would be dominated by one $\mathrm{S}$ cone, and $60 \%$ instead of all of the $S$ cones would dominate at least one ganglion cell.

\section{Discrete classes or continuum?}

Division of BY ganglion cells by number of principal S cones may be a useful description of an underlying continuum, or it may correspond to actual, discrete types. For examination of this issue, we used the array closest to the facts, the one in Figure $7 B$ with four real $S$ cones, approximately balanced numbers of inputs to bipolar cells, and the 14/28 division of bipolar output. For the 16 ganglion cells in that array, Figure $9 A$ shows the synaptic weight ratios (S1/S2 and S2/S3) that we used to determine the type of ganglion cell, with regions labeled to indicate one, two, and three principal S cones. We can also take advantage of the 320 ganglion cells in the 20 random arrays that follow the same constraints, and those data are shown in Figure $9 B$. The positions of ganglion cells in these plots do not fall into discrete clusters, suggesting that number of principal $S$ cones is a useful description of an underlying continuum.

\section{Discussion}

The three-tiered circuits investigated here address a puzzle. Each $\mathrm{L}$ and $\mathrm{M}$ cone in the fovea has a 1:1:1 relationship to its $\mathrm{ON}$ midget bipolar cell and $\mathrm{ON}$ midget ganglion cell; but for each $\mathrm{S}$ cone there are two S-cone ON bipolar cells and two BY ganglion 

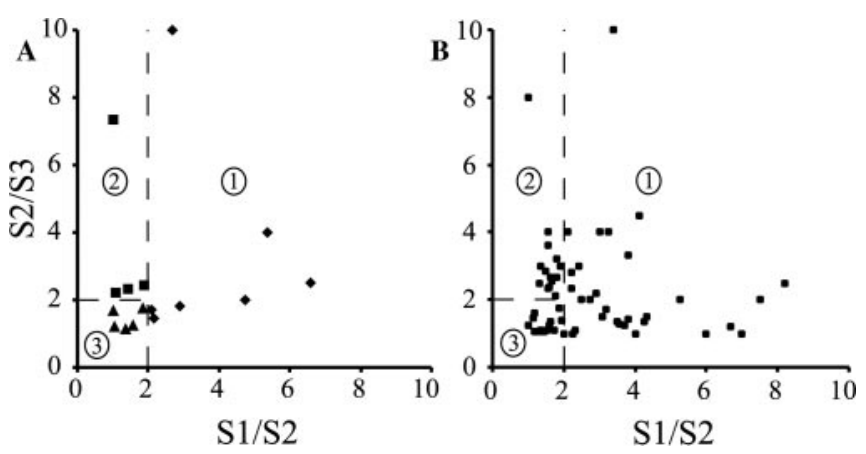

Figure 9. Synaptic weight ratios do not cluster. $A$, Synaptic weight ratios for 16 ganglion cells in the array in Figure $7 B$ with four real $S$ cones, balanced input to bipolar cells, and a 14/28 distribution of outputs from bipolar cells to ganglion cells. If $S 1 / S 2 \geq 2$, the ganglion cell is dominated by one $S$ cone. If $S 1 / S 2<2$ but $S 2 / S 3 \geq 2$, the ganglion cell has two principal $S$ cones; otherwise, it has three. $B$, Synaptic weight ratios for 320 ganglion cells in 20 random arrays with the same constraints as in $A$.

cells (Herr et al., 2003). Here, we offer a possible reason for this divergence: it generates one BY ganglion cell that may be described as having a small receptive field, dominated by one $S$ cone, and another that may be described as having a larger receptive field, contributed by several $\mathrm{S}$ cones (Figs. $4 E, 5 B$ ). Thus, the divergence extends the range of spatial frequencies (and probably also temporal frequencies) that this color-opponent system can transmit. In this respect, it may serve a purpose similar to divergence in the achromatic system, in which a midget ganglion cell is dominated by one L or M cone and a parasol ganglion cell collects from several cones (Derrington and Lennie, 1984; Kaplan and Shapley, 1986; Schiller et al., 1990a,b; Merigan et al., 1991).

The pattern elucidated here for the fovea (one narrow-field plus one wider-field ganglion cell for each $\mathrm{S}$ cone) apparently holds in peripheral retina as well, where BY ganglion cells with narrow and wide dendritic fields are found at each location (Dacey et al., 2003). Furthermore, the weightings calculated here from the numbers of ribbon synapses (see Appendix) match well the weightings measured in peripheral retina by simultaneous recordings from several BY ganglion cells (Chichilnisky and Baylor, 1999). Those recordings showed the following: (1) BY ganglion cells were driven by several S cones; (2) for some ganglion cells, one $\mathrm{S}$ cone dominated, but for other ganglion cells, the weights were more broadly distributed; and (3) several ganglion cells may share the same S cone, but (4) an S cone that dominated one ganglion cell did not dominate another. Such agreement suggests that the standard pattern elucidated here is not an accident of our necessarily limited sample but truly represents the synaptic organization of the BY ON system.

This conclusion seems further supported by our tests of the various wiring constraints. The key findings hold even when we relax many of the these apparent constraints on connectivity: (1) the number of $S$ cones that activate a ganglion cell is not critical because both three and four give the same qualitative result (Figs. $5 B, 6 B)$; (2) partitioning of synaptic outputs from the bipolar cells to BY ganglion cells is not critical because both one-third/ two-thirds and one-half/one-half partitionings give the same qualitative result (Figs. 6A, 7C); and (3) step-like distribution of number of outputs from $S$ cones is not critical because random numbers of synapses between $\mathrm{S}$ cones and S-cone ON bipolar cells give the same qualitative results (Figs. 7, 8). Finally, although the percentages of ganglion cells dominated by one $S$ cone and of $S$ cones that dominate at least one ganglion cell are greater when different bipolar cells pool approximately equal numbers of
S-cone inputs, as is likely, the percentages are still large even without this constraint.

\section{Correspondence to psychophysics}

The map of "hot spots" of sensitivity to short wavelengths in the human fovea suggested that each spot represented one $S$ cone (Williams et al., 1981). This mapping agreed with the Nyquist limit predicted from S-cone spacing mapped by immunostaining (Curcio et al., 1991) and other psychophysical measurements (Stiles, 1949; Green, 1968; Cavonius and Estévez, 1975; Metha and Lennie, 2001). The present results, that every $S$ cone has what amounts to a private ON pathway, certainly support this conclusion. However, we know that every foveal S cone also contacts an OFF midget bipolar cell and thus an OFF midget ganglion cell (Klug et al., 2003). Thus, there are two candidate cells that might explain the psychophysics: a BY ganglion cell dominated by one $S$ cone and an OFF midget ganglion cell, also activated by one $S$ cone.

Under conditions that isolate $\mathrm{S}$ cones, three bandpass spatial frequency channels have been identified with receptive fields larger than S-cone spacing (Humanski and Wilson,1992, 1993). However, these are luminance channels that receive input from all three cone types and appear to be unrelated to the specific S-cone ON and OFF pathway described here and by Klug et al. (2003).

\section{The critical locus for BY color vision}

Because of axial chromatic aberration, the diameter of the blur circle for short-wavelength light is approximately equal to the spacing of S cones (Williams et al., 1983, 1993; Curcio et al., 1991; Marimont and Wandell, 1994; Wandell, 1995). Because the patch of foveal retina that we studied has $120 \mathrm{~L} / \mathrm{M}$ cones for $6 \mathrm{~S}$ cones (Ahmad et al., 2003; Klug et al., 2003), or 20 for 1, the blur circle centered on a foveal S cone spans $\sim 20 \mathrm{~L} / \mathrm{M}$ cones. From study of the identical patch of foveal retina, we know that the group of OFF diffuse bipolar cells that contact a foveal BY ganglion cell collects input from $\sim 20 \mathrm{~L} / \mathrm{M}$ cones (Calkins et al., 1998). Thus, where a BY ganglion cell collects from just one $\mathrm{S}$ cone, the spatial match of its blue-ON and yellow-OFF receptive fields could be explained at the level of the bipolar-to-ganglion cell inputs.

Where a BY ganglion cell collects strongly from several S cones, however, as we show here for approximately half of the BY ganglion cells, its blue-ON component must extend considerably beyond the yellow-OFF component provided by the OFF bipolar cells. This discrepancy led us to suggest that $\mathrm{H} 2$ horizontal cells, which collect $\mathrm{M} / \mathrm{L}$ input and feedback negatively to S-cone terminals (Ahnelt and Kolb, 1994a,b; Dacey et al., 1996; Lee et al., 1999; Verweij et al., 2003), provide each S-cone with a yellowOFF receptive field coextensive with its intrinsic blue-ON field (Herr et al. 2003).

This hypothesis, invoking yellow-OFF surrounds in S cones, could also explain how the yellow-OFF component can balance simultaneously a strong input from one $\mathrm{S}$ cone to one BY ganglion cell and a weak input from the same $S$ cone to a different BY ganglion cell (Figs. 5B, 6, 7). Indeed, most of the yellow-OFF signal recorded in BY ganglion cells is blocked by L-2-amino-4-phosphonobutyate (Dacey, 2000), a drug that blocks activity in ON bipolar cells (Slaughter and Miller, 1981; Schiller et al., 1986).

Because its receptive field is cone opponent ( $\mathrm{S}$ vs $\mathrm{L}+\mathrm{M}$ ) but not spatially opponent, the BY ganglion cell was suggested as the first "critical locus for BY color vision" (Rodieck, 1998). In that case, the opponent mechanism would originate in the dendritic tips of the $\mathrm{S}$-cone ON bipolar cells, which have the sign-inverting mGluR6 glu- 
tamate receptor, and the $\mathrm{M} / \mathrm{L}$-cone OFF bipolar cells, which have the sign-preserving ionotropic glutamate receptors (Calkins and Sterling, 1999). However, the S-cone terminal itself, by virtue of antagonistic signals from neighboring $\mathrm{L}$ and $\mathrm{M}$ cones conveyed by $\mathrm{H} 2$ horizontal cells, already fits Rodieck's (1998) description. Therefore, we now regard the S-cone terminal itself, rather than the BY ganglion cell, as the first critical locus for BY color vision.

\section{Appendix}

Bistratified ganglion cells linearly combine signals from different $S$ cones, as follows:

$$
G=\boldsymbol{g}\left(w_{1} \times I_{1}+w_{2} \times I_{2}+w_{3} \times I_{3}\right),
$$

where the output $G$ of the ganglion cell (i.e., the change in its spike-firing rate) is a function $\boldsymbol{g}$ of the sum of the products of synaptic weights $w_{1}, w_{2}$, and $w_{3}$ from S cones S1, S2, and S3 and the rate of absorption of photons ("intensities") $I_{1}, I_{2}$, and $I_{3}$ by the three $\mathrm{S}$ cones (Fig. $3 B$ ).

In Equation 2, the output $G$ of the ganglion cell is the same function $g$ of the outputs $B$ and $B^{\prime}$ of the two bipolar cells weighted by the numbers of ribbon synapses $d$ and $d^{\prime}$ between each of these bipolar cells and the ganglion cell (Fig. 3B):

$$
G=\boldsymbol{g}\left(d \times B+d^{\prime} \times B^{\prime}\right) .
$$

In Equation 3, the output $B$ of the one bipolar cell is a function $\boldsymbol{b}$ of the rate of absorption of photons $I_{1}$ by $S$ cone $S 1$ and $I_{2}$ by $S$ cone $S 2$, weighted by the numbers of ribbon synapses (central elements) $c_{1}$ and $c_{2}$ (Fig. $3 B$ ):

$$
B=\boldsymbol{b}\left(c_{1} \times I_{1}+c_{2} \times I_{2}\right) .
$$

The output $B^{\prime}$ of the other bipolar cell is provided in Equation 3':

$$
B^{\prime}=\boldsymbol{b}\left(c_{2^{\prime}} \times I_{2}+c_{3^{\prime}} \times I_{3}\right) .
$$

Combining Equations 2, 3, and 3' gives the following:

$$
G=\boldsymbol{g}\left[\boldsymbol{d} \times \boldsymbol{b}\left(c_{1} \times I_{1}+c_{2} \times I_{2}\right)+d^{\prime} \times \boldsymbol{b}\left(c_{2^{\prime}} \times I_{2}+c_{3^{\prime}} \times I_{3}\right)\right] .
$$

In order for this equation to obey the linearity constraint (Eq. 1), function $\boldsymbol{b}$ must be a constant (i.e., simply $b$ ):

$$
\begin{aligned}
& w_{1}=d \times b \times c_{1}, \\
& w_{2}=d \times b \times c_{2}+d^{\prime} \times b \times c_{2^{\prime}}, \\
& w_{3}=d^{\prime} \times b \times c_{3^{\prime}} .
\end{aligned}
$$

Thus, the synaptic weight from an individual $S$ cone onto a BY ganglion cell is the product of the number $c$ of ribbon synapses between that $S$ cone and the central elements of its bipolar cell(s), represented by number of blue bonds, and the number $\mathrm{d}$ of ribbon synapses between the bipolar cell(s) and the ganglion cell, represented by the number of green bonds (Figs. $3 B, 4 E, G$ ).

\section{References}

Ahmad KM, Klug K, Herr S, Sterling P, Schein S (2003) Cell density ratios in a foveal patch in macaque retina. Vis Neurosci 20:189-209.

Ahnelt P, Kolb H (1994a) Horizontal cells and cone photoreceptors in primate retina: a Golgi-light microscopic study of spectral connectivity. J Comp Neurol 343:387-405.

Ahnelt P, Kolb H (1994b) Horizontal cells and cone photoreceptors in human retina: a Golgi-electron microscopic study of spectral connectivity. J Comp Neurol 343:406-427.

Bumsted K, Hendrickson A (1999) Distribution and development of short- wavelength cones differ between Macaca monkey and human fovea. J Comp Neurol 403:502-516.

Burris C, Klug K, Ngo IT, Sterling P, Schein S (2002) How Müller glial cells in macaque fovea coat and isolate the synaptic terminals of cone photoreceptors. J Comp Neurol 453:100-111.

Calkins DJ, Sterling P (1999) Evidence that circuits for spatial and color vision segregate at the first retinal synapse. Neuron 24:313-321.

Calkins DJ, Tsukamoto Y, Sterling P (1996) Foveal cones form basal as well as invaginating junctions with diffuse on bipolar cells. Vis Neurosci 36:3373-3381.

Calkins DJ, Tsukamoto Y, Sterling P (1998) Microcircuitry and mosaic of a blue-yellow ganglion cell in the primate retina. J Neurosci 18:3373-3385.

Cavonius CR, Estévez O (1975) Contrast sensitivity of individual color mechanisms of human vision. J Physiol (Lond) 248:649-662.

Chichilnisky EJ, Baylor DA (1999) Receptive-field microstructure of blueyellow ganglion cells in primate retina. Nat Neurosci 2:889-893.

Chun M, Grünert U, Martin P, Wässle H (1996) The synaptic complex of cones in the fovea and in the periphery of the macaque monkey retina. Vision Res 36:3383-3395.

Curcio CA, Allen KA, Sloan KR, Lerea CL, Hurley JB, Klock IB, Milam AB (1991) Distribution and morphology of human cone photoreceptors stained with anti-blue opsin. J Comp Neurol 312:610-624.

Dacey DM (1993) Morphology of a small-field bistratified ganglion cell type in the macaque and human retina. Vis Neurosci 10:1081-1098.

Dacey DM (2000) Parallel pathways for spectral coding in primate retina. Ann Rev Neurosci 23:743-775.

Dacey DM, Lee BB (1994) The "blue-on" opponent pathway in primate retina originates from a distinct bistratified ganglion cell type. Nature 367:731-735.

Dacey DM, Lee BB, Stafford DK, Pokorny J, Smith VC (1996) Horizontal cells of the primate retina: cone specificity without spectral opponency. Science 271:656-659.

Dacey DM, Peterson BB, Robinson FR, Gamlin PD (2003) Fireworks in the primate retina: in vitro photodynamics reveals diverse LGN-projecting ganglion cell types. Neuron 37:15-27.

de Monasterio FM, Gouras P (1975) Functional properties of ganglion cells of the rhesus monkey retina. J Physiol (Lond) 251:167-195.

de Monasterio FM, Schein SJ, McCrane EP (1981) Staining of blue-sensitive cones of the macaque retina by a fluorescent dye. Science 213:1278-1281.

de Monasterio FM, McCrane EP, Newlander JK, Schein SJ (1985) Density profile of blue-sensitive cones along the horizontal meridian of macaque retina. Invest Ophthalmol Vis Sci 26:289-302.

Derrington AM, Lennie P (1984) Spatial and temporal contrast sensitivities of neurones in lateral geniculate nucleus of macaque. J Physiol (Lond) 357:219-240

Ghosh KK, Martin PR, Grünert U (1997) Morphological analysis of the blue cone pathway in the retina of a new world monkey, the marmoset Callithrix jacchus. J Comp Neurol 379:211-225.

Green DG (1968) The contrast sensitivity of the color mechanisms of the human eye. J Physiol (Lond) 196:415-429.

Herr S, Klug KJ, Sterling P, Schein S (2003) Inner S-cone bipolar cells provide all of the central elements for $\mathrm{S}$ cones in macaque retina. J Comp Neurol 457:185-201.

Hopkins JM, Boycott BB (1995) Synapses between cones and diffuse bipolar cells of a primate retina. J Neurocytol 24:680-694.

Hopkins JM, Boycott BB (1996) The cone synapses of DB1 diffuse, DB6 diffuse and invaginating midget, bipolar cells of a primate retina. J Neurocytol 25:381-390.

Hopkins JM, Boycott BB (1997) The cone synapses of cone bipolar cells of primate retina. J Neurocytol 26:313-325.

Humanski RA, Wilson HR (1992) Spatial frequency mechanisms with short-wavelength-sensitive cone inputs. Vision Res 32:549-560.

Humanski RA, Wilson HR (1993) Spatial-frequency adaptation: evidence for a multiple-channel model of short-wavelength-sensitive-cone spatial vision. Vision Res 33:665-675.

Kaplan E, Shapley RM (1986) The primate retina contains two types of ganglion cells, with high and low contrast sensitivity. Proc Natl Acad Sci USA 83:2755-2757.

Klug K, Herr S, Ngo IT, Sterling P, Schein S (2003) Macaque retina contains an S-cone OFF midget pathway. J Neurosci 23:9881-9887.

Kolb H, Goede P, Roberts S, McDermott R, Gouras P (1997) Uniqueness of 
the S-cone pedicle in the human retina and consequences for color processing. J Comp Neurol 386:443-460.

Kouyama N, Marshak DW (1992) Bipolar cells specific for blue cones in the macaque retina. J Neurosci 12:1233-1252.

Kouyama N, Marshak DW (1997) The topographical relationship between two neuronal mosaics in the short wavelength-sensitive system of the primate retina. Vis Neurosci 14:159-167.

Lee BB, Dacey DM, Smith VC, Pokorny J (1999) Horizontal cells reveal cone type-specific adaptation in primate retina. Proc Natl Acad Sci USA 96:14611-14616.

Mariani AP (1984) Bipolar cells in monkey retina selective for the cones likely to be blue-sensitive. Nature 308:184-186.

Marimont D, Wandell B (1994) Matching color images: the effects of axial chromatic aberration. J Opt Soc Am [A] 12:3113-3122.

McCrane EP, de Monasterio FM, Schein SJ, Caruso RC (1983) Nonfluorescent staining of primate blue cones. Invest Ophthal Vis Sci 24:1449-1455.

Merigan WH, Katz LM, Maunsell JH (1991) The effects of parvocellular lateral geniculate lesions on the acuity and contrast sensitivity of macaque monkeys. J Neurosci 11:994-1001.

Metha AB, Lennie P (2001) Transmission of spatial information in S-cone pathways. Vis Neurosci 18:961-972.

Meyers D, Skinner S, Sloan K (1992) Surfaces from contours. ACM Trans Graph 11:228-258.

Migdale K, Herr S, Klug K, Ahmad K, Linberg K, Sterling P, Schein SJ (2003) Two ribbon synaptic units in rod photoreceptors of macaque, human, and cat. J Comp Neurol 455:100-112.

Polyak SL (1941) The retina, p 198. Chicago: University of Chicago.

Rodieck RW (1991) Which cells code for color? In: From pigments to perception: advances in understanding visual processes (Valberg A, Lee BB, eds), pp 83-89. New York: Plenum.

Rodieck RW (1998) The first steps in seeing. Sunderland, MA: Sinauer.

Schein SJ (1988) Anatomy of macaque fovea and spatial densities of neurons in foveal representation. J Comp Neurol 269:479-505.

Schiller PH, Sandell JH, Maunsell JH (1986) Functions of the ON and OFF channels of the visual system. Nature 322:824-825.

Schiller PH, Logothetis NK, Charles ER (1990a) Functions of the colouropponent and broad-band channels of the visual system. Nature $343: 68-70$
Schiller PH, Logothetis NK, Charles ER (1990b) Role of the color-opponent and broad-band channels in vision. Vis Neurosci 5:321-346.

Shapiro MB, Schein SJ, de Monasterio FM (1985) Regularity and structure of the spatial pattern of blue cones of macaque retina. J Am Stat Assoc 80:803-814.

Slaughter MM, Miller RF (1981) 2-Amino-4-phosphonobutyric acid: a new pharmacological tool for retina research. Science 211:182-185.

Smith RG (1987) Montage: a system for three-dimensional reconstruction by personal computer. J Neurosci Methods 21:55-69.

Stiles WS (1949) Increment thresholds and the mechanism of color vision. Doc Ophthalmol 3:138-163.

Szél A, Diamanstein T, Röhlich P (1988) Identification of the blue-sensitive cones in the mammalian retina by anti-visual pigment antibody. J Comp Neurol 273:593-602.

Tsukamoto Y, Masarachia P, Schein SJ, Sterling P (1992) Gap junctions between the pedicles of macaque foveal cones. Vision Res 32:1809-1815.

Vardi N, Duvoisin R, Wu G, Sterling P (2000) Localization of.mGluR6 to dendrites of ON bipolar cells in primate retina. J Comp Neurol 423:402-412.

Verweij J, Hornstein EP, Schnapf JL (2003) Surround antagonism in macaque cone photoreceptors. J Neurosci 23:10249-10257.

Wandell BA (1995) Foundations of vision. Sunderland, MA: Sinauer.

Wässle H, Boycott BB (1991) Functional architecture of the mammalian retina. Physiol Rev 71:447-480.

Wässle H, Grünert U, Martin PR, Boycott BB (1994) Immunocytochemical characterization and spatial distribution of midget bipolar cells in the macaque monkey retina. Vision Res 34:561-579.

Wiesel TN, Hubel DH (1966) Spatial and chromatic interactions in the lateral geniculate body of the rhesus monkey. J Neurophysiol 9:1115-1156.

Wikler KC, Rakic P (1990) Distribution of photoreceptor subtypes in the retina of diurnal and nocturnal primates. J Neurosci 10:3390-3401.

Williams DR, MacLeod DI, Hayhoe MM (1981) Punctate sensitivity of the blue-sensitive mechanism. Vision Res 21:1357-1376.

Williams DR, Collier RJ, Thompson BJ (1983) Spatial resolution of the short wavelength mechanism. In: Color vision: physiology and psychophysics (Mollon J, Sharpe L, eds), pp 487-503. New York: Academic.

Williams DR, Sekiguchi N, Brainard D (1993) Color, contrast sensitivity, and the cone mosaic. Proc Natl Acad Sci USA 90:9770-9777. 